\title{
NUMERICAL MODELING OF COASTAL INUNDATION AND SEDIMENTATION BY STORM SURGE, TIDES, AND WAVES AT NORFOLK, VIRGINIA, USA
}

\author{
Honghai Li ${ }^{1}$, Lihwa Lin ${ }^{1}$, and Kelly A. Burks-Copes ${ }^{2}$
}

\begin{abstract}
A nearshore hydrodynamic and sediment transport model was developed to simulate synthetic storms with design SLR scenarios surrounding the military installations in Norfolk, Virginia. Foreseeable risk and effect of storm surge damage accompanied by waves, tides, and Sea Level Rise (SLR) were examined. The final results include the evaluation of impacts for five SLR $(0.0,0.5,1.0,1.5$, and $2.0 \mathrm{~m})$ and three storm conditions $(50$-yr, 100-yr return tropical storms, and a winter storm). Associated with the storm surge and SLR, extensive inundation will occur at the Naval Station Norfolk, approximately $70-80 \%$ of the Naval Station Norfolk under the 2-m SLR scenario. The calculated morphology changes indicate that the sediment movement mostly occurs in the navigation channels and the maximum depth changes are more than $3.0 \mathrm{~m}$ along the channels. The bed volume changes show that the storms induce a net volume loss within the channel area, an indication of channel flushing in the study area.
\end{abstract}

Keywords: storm surge; sea level rise; waves; coastal inundation; coastal modeling; coastal sedimentation

\section{INTRODUCTION}

Global sea level rise, combined with frequent coastal storms, can cause increased damage to coastal infrastructures, continuous coastal erosion, and rapid shoreline change (McLean et al. 2001). Recognizing the climate change and sea level rise threats to coastal residents and coastal military facilities, the US Strategic Environmental Research and Development Program (SERDP) funds a research initiative to develop technologies in quantitative risk assessment and to provide decisionmakers with relevant guidance regarding existing and future coastal infrastructure development.

Naval Station Norfolk, Virginia, is selected as a demonstration site for the risk assessment study. A nearshore hydrodynamic and sediment transport model was developed to simulate synthetic storms with design SLR scenarios and to understand the effects of sea level rise and coastal storms on changes in both installations and natural systems.

\section{METHOD}

The Coastal Modeling System (CMS) was selected and applied to the present study. The CMS, developed by the Coastal Inlets Research Program (CIRP) at the Coastal and Hydraulics Laboratory (http://cirp.usace.army.mil), is an integrated suite of numerical models for simulating water surface elevation, current, waves, sediment transport, and morphology change for coastal and inlet applications. It has the capabilities of identifying water bottom and land surface erosion and accretion areas in extreme storms. The CMS consists of a hydrodynamic model, CMS-Flow, and a spectral wave model, CMS-Wave. CMS-Flow and CMS-Wave are coupled and operated through a Steering Module developed within the Surface-water Modeling System (SMS) (Zundel 2006).

CMS-Flow is a three-dimensional (3D) finite-volume model that solves the mass conservation and shallow-water momentum equations of water motion on a non-uniform Cartesian grid. Three sediment transport formulations are available: a sediment mass balance, an equilibrium advection-diffusion method, and non-equilibrium advection-diffusion transport. The model can run in a two-dimensional (2D) mode based on the depth-integrated continuity equation. The wave radiation stress and wave field information calculated by CMS-Wave are supplied to CMS-Flow for the flow and sediment transport calculations. Currents, water level, and morphology changes are feeding to CMS-Wave to increase the accuracy of the wave transformation predictions (Buttolph et al. 2006) (Figure 1).

${ }^{1}$ US Army Engineer Research Development Center, Coastal and Hydraulics Laboratory, 3909 Halls Ferry Road, Vicksburg, MS 39180, USA

2 US Army Engineer Research Development Center, Environmental Laboratory, 3909 Halls Ferry Road, Vicksburg, MS 39180, USA 


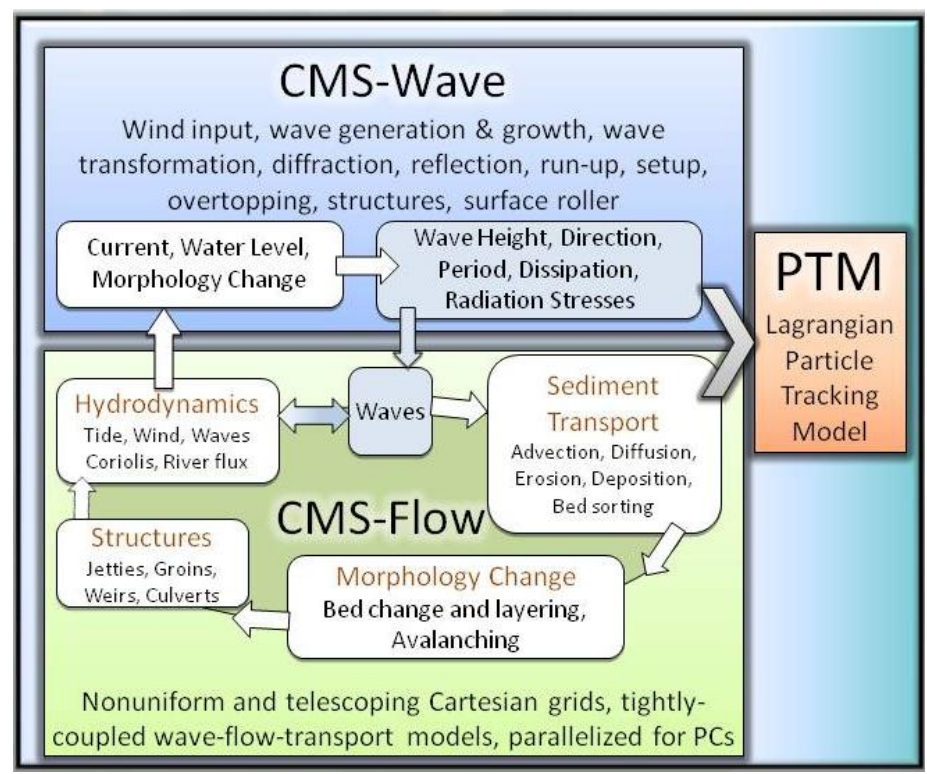

Figure 1. The CMS operational flow chart.

CMS-Wave is a two-dimensional spectral wave transformation model that solves the steady-state wave-action balance and diffraction equation on a non-uniform Cartesian grid (Lin et al. 2008). The model can simulate important wave processes at coastal inlets including diffraction, refraction, reflection, wave breaking and dissipation mechanisms, wave-wave and wave-current interactions, and wave generation and growth. It is a full-plane model with primary waves propagating from open boundaries toward inside domain. If the reflection option is selected from one open boundary, CMSWave will perform a backward marching for the boundary reflection after the forwarding-marching calculation is completed. The fundamental wave diffraction process is theoretically developed and calculated in the wave-action balance equation (Mase 2001). Additional model features include the grid nesting capability, variable rectangle cells, wave run-up on beach face, wave transmission through structures, wave overtopping, and storm wave generation (Figure 1).

Figure 2 shows the modeling framework of the study. Under different sea level rise scenarios the first assessments are conducted at a regional scale, including geomorphologic, environmental, and regional surge and wave simulations. The nearshore waves, current, surge, and sediment transport model receives waves, surge, and wind conditions from the regional storm surge and wave models, ADCIRC (Melby et al. 2005) and SWAN (http://www.swan.tudelft.nl). Local water levels (surge and tides), waves, currents, sediment transport, and morphology changes are extracted and transferred to Gridded Surface/Subsurface Hydrologic Analysis (GSSHA) Model (Downer and Ogden, 2004) and structure analysis model (ISS3D and HAZUS-MH MR-4) (Slawson and Brokaw 1995; http://www.fema.gov/plan/prevent/hazus/). 


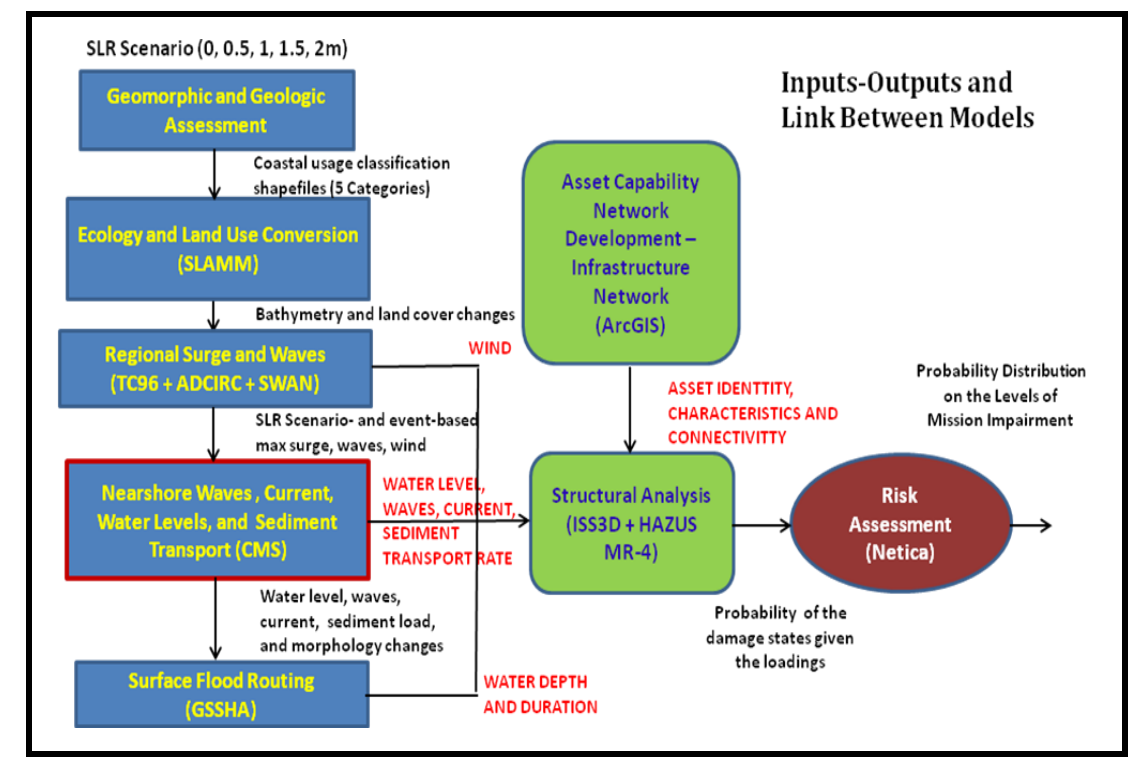

Figure 2. Modeling framework for risk assessment of the Naval Station Norfolk under four sea level rise scenarios. The red frame indicates the CMS effort.

Based on extensive literature review, the sea level rise scenarios are designed as 0 (existing condition), 0.5, 1.0, 1.5, and 2 m over a 100 year period between 2000 and 2100. The selection of storms includes two synthetic hurricanes (tropical) with a 50-year and a 100-year return period, and one winter storm (extratropical) occurred in October 1982. There are a total of 15 simulations conducted and each simulation is set up for a four-day duration covering a 12-hour ramping of transition from normal to storm condition, and the passage of a storm.

\section{DATA}

A collection of detail coastline information, accurate topographic data, and land surface features in the Hampton Roads area are required to set up a small-scale, high-resolution storm surge and sediment transport model for the Naval Station Norfolk.

Coastline information around the Naval Station Norfolk and the Hampton Roads area, Virginia, was extracted for this study from the shoreline database of the National Geophysical Data Center (NGDC) of NOAA (http://www.ngdc.noaa.gov/mgg/shorelines/shorelines). The aerial photographs were downloaded from Google Earth Pro 5.1 (http://earth.google.com).

LIDAR network provides the land detail topography in the Naval Station Norfolk. The data at a 1m resolution allow the CMS to describe local land features, such as buildings, roads, airport, and other infrastructures in the area. Topographic information of other land areas and bathymetry for the water domain were provided by a $10-\mathrm{m}$ resolution coastal Digital Elevation Model (DEM) of Virginia Beach (Taylor et al. 2008). Figure 3 shows water depth and land surface topography contours, relative to mean sea level (MSL), from the two datasets. The figure displays the deep-draft Hampton Roads navigation channel running across north of the domain, the Norfolk Harbor entrance channel, and a few small channels to the military piers on the Naval Station water front. The data ranges from the highest elevation of more than $10 \mathrm{~m}$ on land (negative values) to more than $30 \mathrm{~m}$ in the navigation channel (positive values). The red color in the lower left corner indicates the Craney Island Dredged Material Management Area. The dikes built surrounding the area have a height of about $12 \mathrm{~m}$ above MSL. 


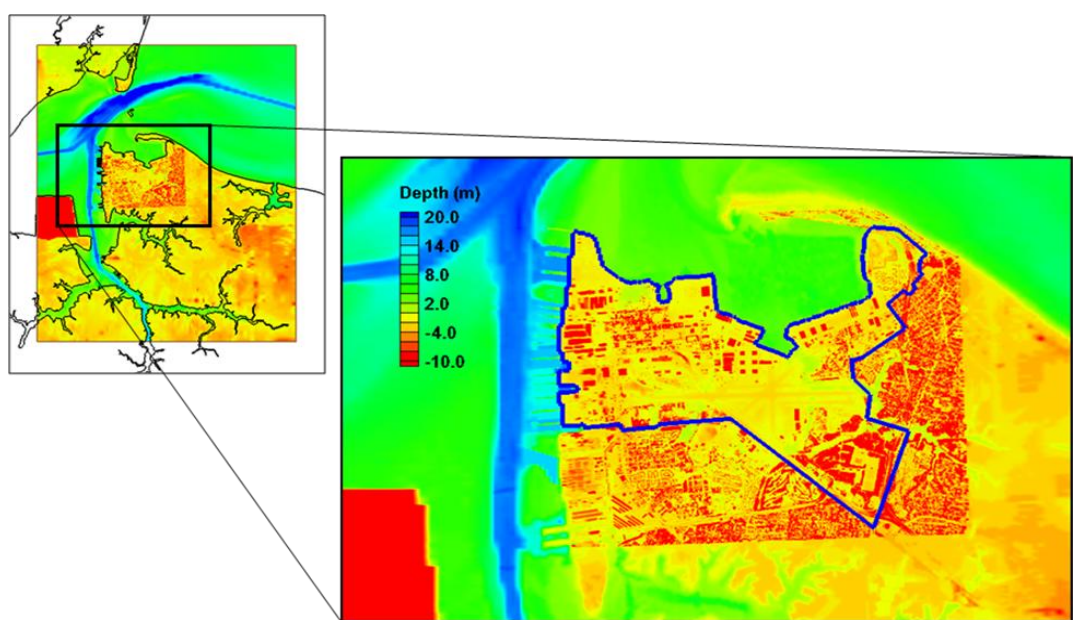

Figure 3. Topographic map of the study area. The blue line outlines the Naval Station Norfolk.

The land coverage data reflect detail land features in the Naval Station Norfolk. Figure 4 shows different land coverages of grass, forest, concrete, and dirt road. Based on these data, sediment grain size, erodibility, and bottom friction were specified in the CMS (Table 1). Because the Naval Station Norfolk and its surrounding area are largely covered by concrete surface and buildings, a large part of land surface was specified as non-erodible. A median grain size of $0.2 \mathrm{~mm}$ was specified for the ocean part of the study domain.

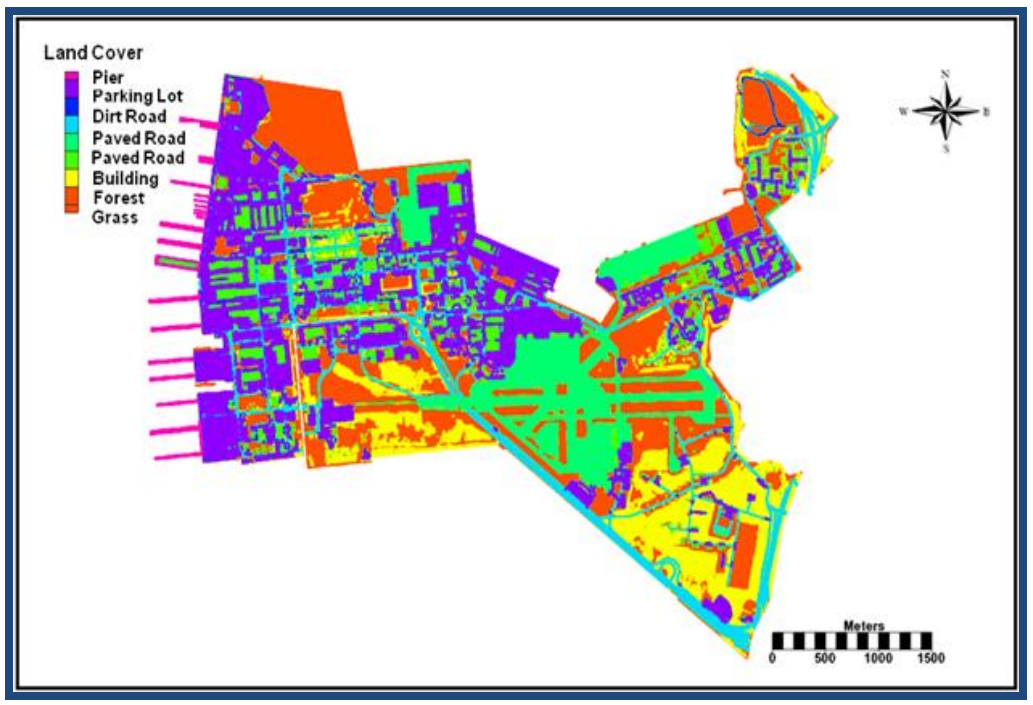

Figure 4. Land coverage $(5 \times 5 \mathrm{~m})$ at the Naval Station Norfolk.

\begin{tabular}{|c|c|c|}
\hline Land Coverage & Erodibility & Grain Size $(\mathrm{mm})$ \\
\hline Grass & None & $\mathrm{N} / \mathrm{A}$ \\
\hline Forest & Limited & 0.3 \\
\hline Building & None & $\mathrm{N} / \mathrm{A}$ \\
\hline Paved Road & None & $\mathrm{N} / \mathrm{A}$ \\
\hline Dirt Road & Limited & 0.5 \\
\hline Parking Lot & None & $\mathrm{N} / \mathrm{A}$ \\
\hline Pier & $\mathrm{N} / \mathrm{A}$ & $\mathrm{N} / \mathrm{A}$ \\
\hline
\end{tabular}


Forcing to drive the model includes tide, surge, wind and waves. The regional model provides synthetic storms with 50-year and 100-year return periods and a winter storm (northeaster) (BurksCopes and Russo, 2011). Figures 5 and 6 show wind and wave conditions associated with the 100-year return storm, respectively. The wind plots indicate that the tropical storm passing over the study area has a peak speed of $33 \mathrm{~m} / \mathrm{sec}$ (74 miles/hour). Storm waves are propagating from the Chesapeake Bay side with a wave period of $16 \mathrm{sec}$ and a peak wave height greater than $4 \mathrm{~m}$. Tidal data at Sewells Point, VA, are available on the NOAA website, http://tidesandcurrents.noaa.gov. Four-day water surface elevation was downloaded during a spring tidal period and incorporated into the surge of the 2-m sea level rise scenario for the CMS. The combination of the surge and the spring tide increased the maximum water surface elevation by more than half meters (Figure 7).
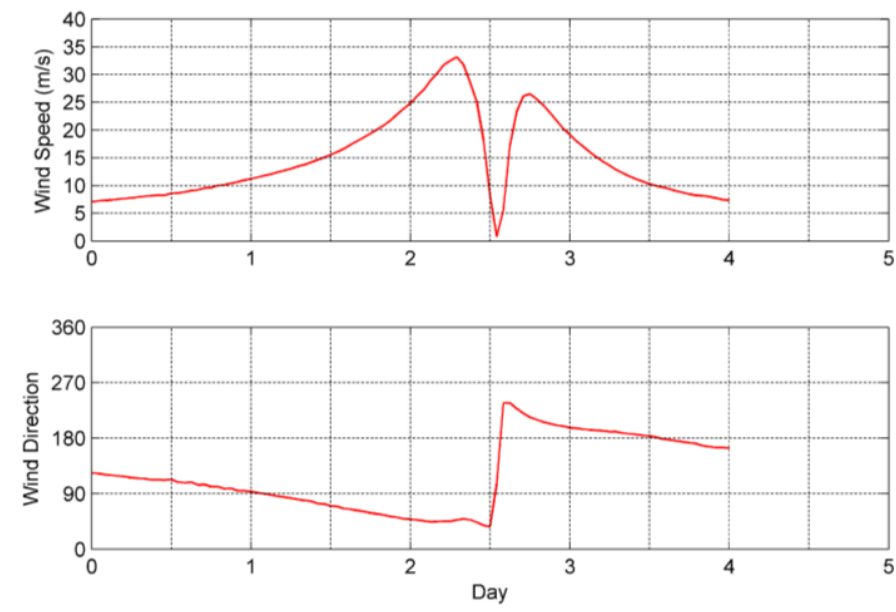

Figure 5. Wind speed and direction of the 100-year return storm.
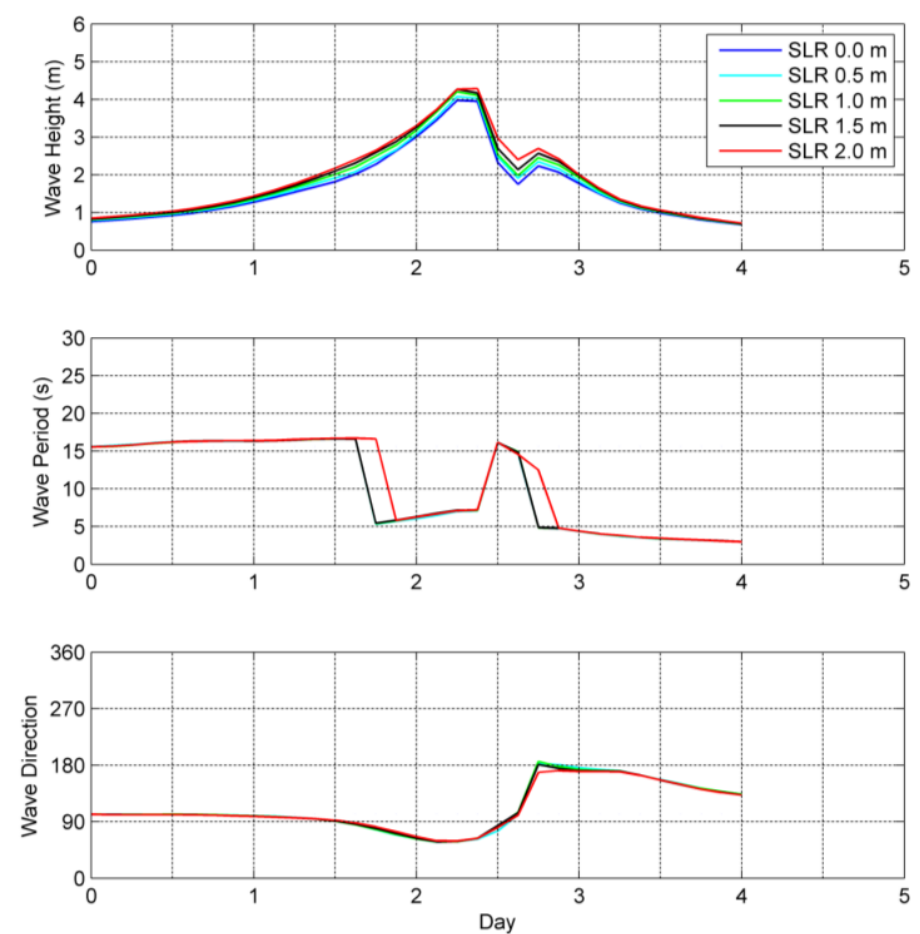

Figure 6. Wave parameters of the 100-year return storm under the existing condition and four sea level rise scenarios. 


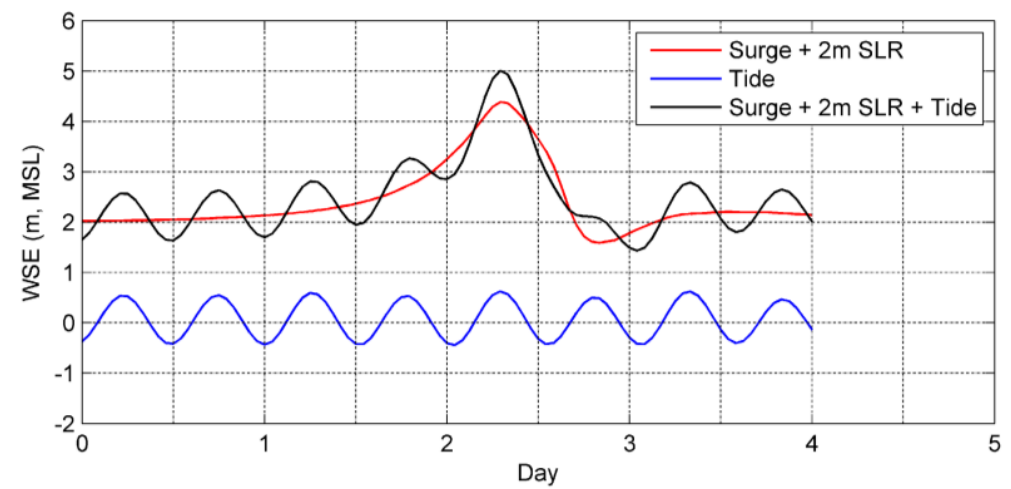

Figure 7. Surge, $2 \mathrm{~m}$ sea level rise, and tide at NOAA GAGE 8638610 (SEWELLS POINT, VA).

Sustained sea level rise will inundate land and create new wetland areas along coastal regions. To accurately calculate nearshore hydrodynamics, storm surge models ought to represent the effects of sea level rise by a change in vegetation types with corresponding adjustments in bottom frictional roughness (McAlpin et al. 2011). Consistent with the regional surge and wave model, the CMS employs four sets of bottom roughness (Manning's $n$ values) for four sea level rise scenarios. For example, in the 2-m sea level rise scenario (Figure 8), a small Manning's $n$ of 0.02 is specified for water covered areas and increases to as large as 0.15 on concrete covered land areas.

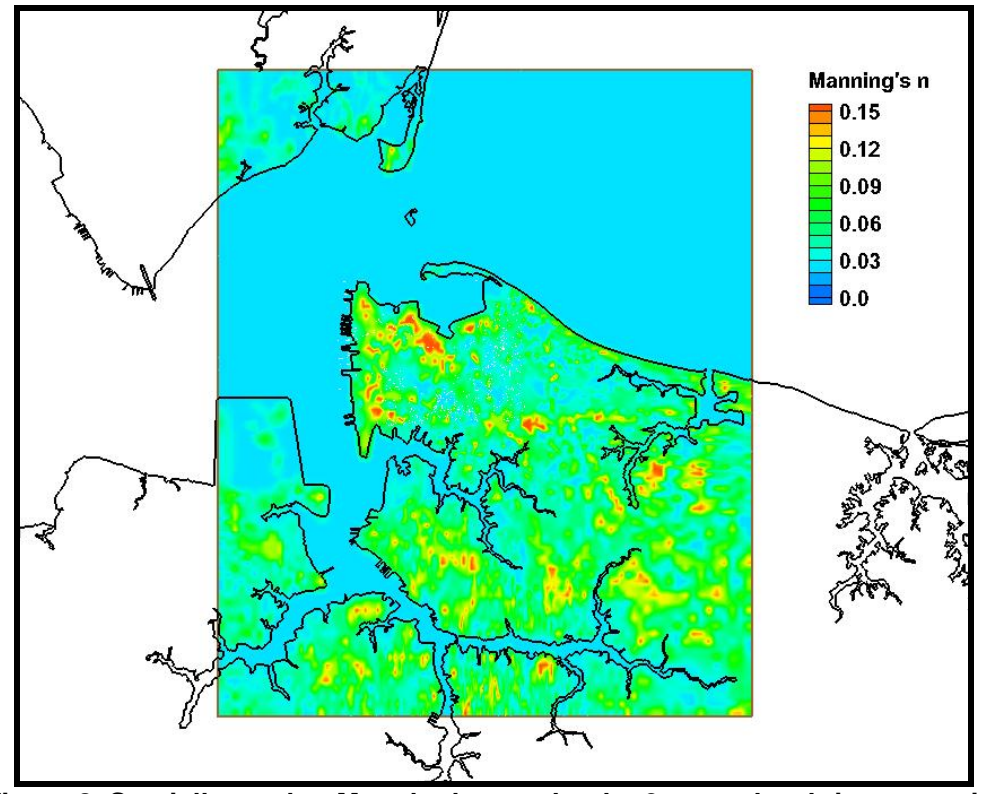

Figure 8. Spatially varying Manning's $n$ under the $2 \mathrm{~m}$ sea level rise scenario.

\section{MODEL}

Figure 9 shows the CMS domain surrounding the Naval Station Norfolk. The area covers the mouths of the James River and the Elizabeth River, and the part of the lower Chesapeake Bay in the Hampton Roads, and extends approximately $20 \mathrm{~km}$ from east to west and $24 \mathrm{~km}$ from north to south. The western open boundary is located in the mouths of the rivers and the northern and eastern open boundary in the Chesapeake Bay. A non-uniform rectangular grid system with more than half million grid cells was created to discretize the entire installation and the nearshore region. The grid system permits much finer resolution $(10 \mathrm{~m})$ in areas of high interest such as the Naval Station Norfolk. The mesh of the regional model, also shown in Figure 9, has been coupled with the CMS through data mapping. 


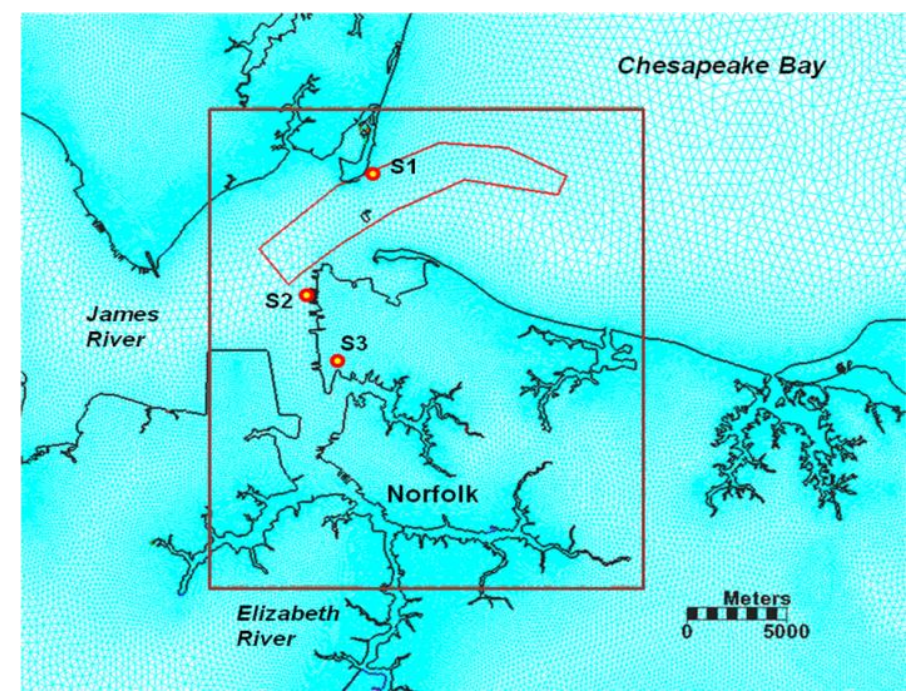

Figure 9. The CMS domain. White dots are time series stations in the Hampton Roads navigation channel (S1), near Naval Piers (S2), and on land (S3). Bed volume change is examined within the red polygon area.

CMS-Flow is driven by offshore water surface elevation (typically from tide and storm surge), wind, waves, and river discharge. CMS-Wave is driven by wave spectra and wind, which are often obtained from offshore ocean buoys. In the dynamic coupling CMS-Wave passes wave radiation stress to CMS-Flow and receives information of current, water surface elevation, and morphology change from CMS-Flow.

The CMS simulations were set up and conducted using the results based on the regional storm analysis. The local wind speed and direction as input to CMS were provided by the storm analysis and wave parameters from SWAN (Figures 5 and 6). Surge information was retrieved from the large scale regional model output and tide data were obtained from the NOAA gage at Sewells Point, VA. The combination of the two datasets provided the water surface elevation forcing along the CMS open boundaries (Figure 7). The bottom friction of the CMS was based on the bottom roughness information provided by the regional model for different sea level rise scenarios. For sediment transport, the grain size distributions of bottom sediment and land erodibility were determined from the detail land coverage features and were input to the CMS.

\section{RESULTS}

\section{Storm Surge}

Figure 10 shows the maximum water surface elevations under the existing condition and the 2-m sea level rise scenarios for the 100-year return storm over the period of the four-day simulations. Land areas besides rivers are quite flat and land elevation is generally $2 \mathrm{~m}$ above MSL in the installation area with higher land at the east of Norfolk. Even for the existing condition, most of the installation area could be under the maximum surge level during a storm. The high land area east of the Naval Station stays above the maximum surge level under the 2-m sea level rise scenario. Another dry area is the Craney Island where the 12-m dikes built surrounding it are protecting the area from the most severe storm and the highest sea level rise scenario. 

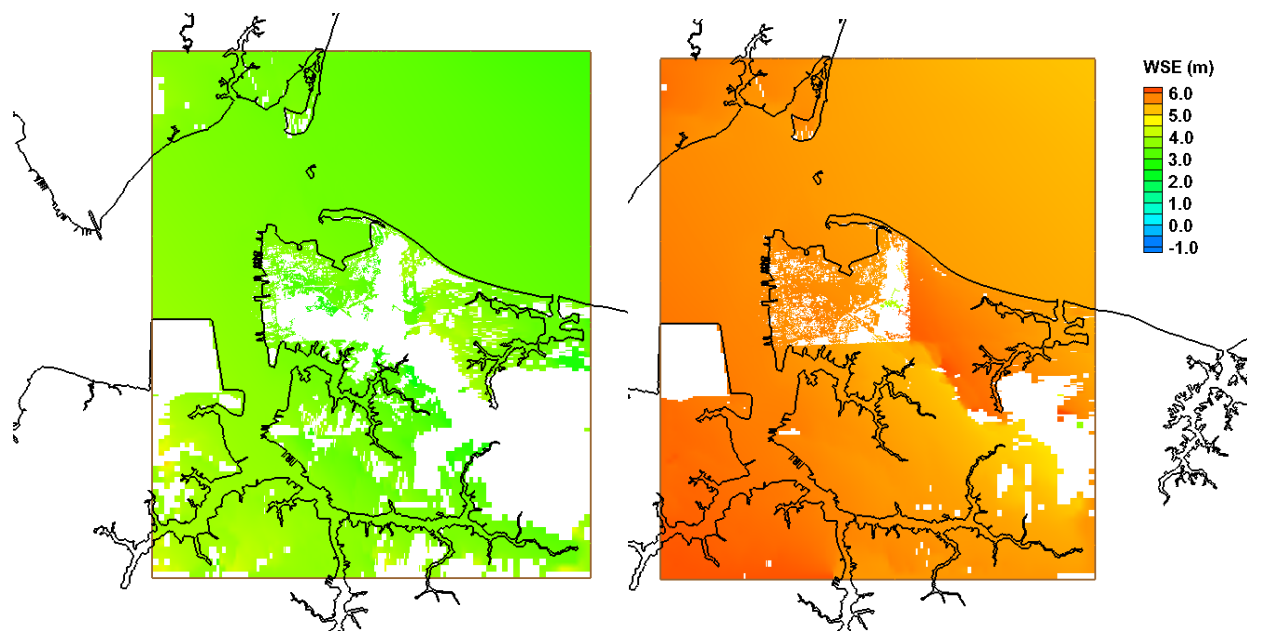

Figure 10. The maximum water surface elevation due to the 100 -year return tropical storm under the existing condition and the $2.0-\mathrm{m}$ sea level rise scenario.

Time series of water surface elevations are analyzed at Sites S1, S2, and S3 (Figure 9), located at the main Hampton Road channel, a small channel, and on land in the Naval Station Norfolk, respectively. Figure 11 illustrates the calculated water surface elevations at the three locations for the existing condition and four sea level rise scenarios over the 100-year return storm period. Tidal and surge signals at Sites 1 and 2 coincide with tidal forcing implemented at the model open boundaries. Water piles up nearshore as tidal waves propagate from open water to the harbor area. Figure 11 shows that the surge level at Site 2 is generally higher than Site 1 and the difference can be as large as $0.5 \mathrm{~m}$. A different inundation picture is shown at Site 3. The regular tidal condition would not flood the installation area for the existing condition, the $0.5-\mathrm{m}$, and $1.0-\mathrm{m}$ sea level rise cases, but would for the $1.5-\mathrm{m}$ and the $2.0-\mathrm{m}$ sea level rise cases. The storm surge would raise the peak water level to $3.6 \mathrm{~m}$ under the existing condition and to $5.4 \mathrm{~m}$ under the $2.0-\mathrm{m}$ sea level rise scenario. The passage of the storm will generate high surge levels and inundate the Naval Station Norfolk under the existing condition and four sea level rise scenarios.

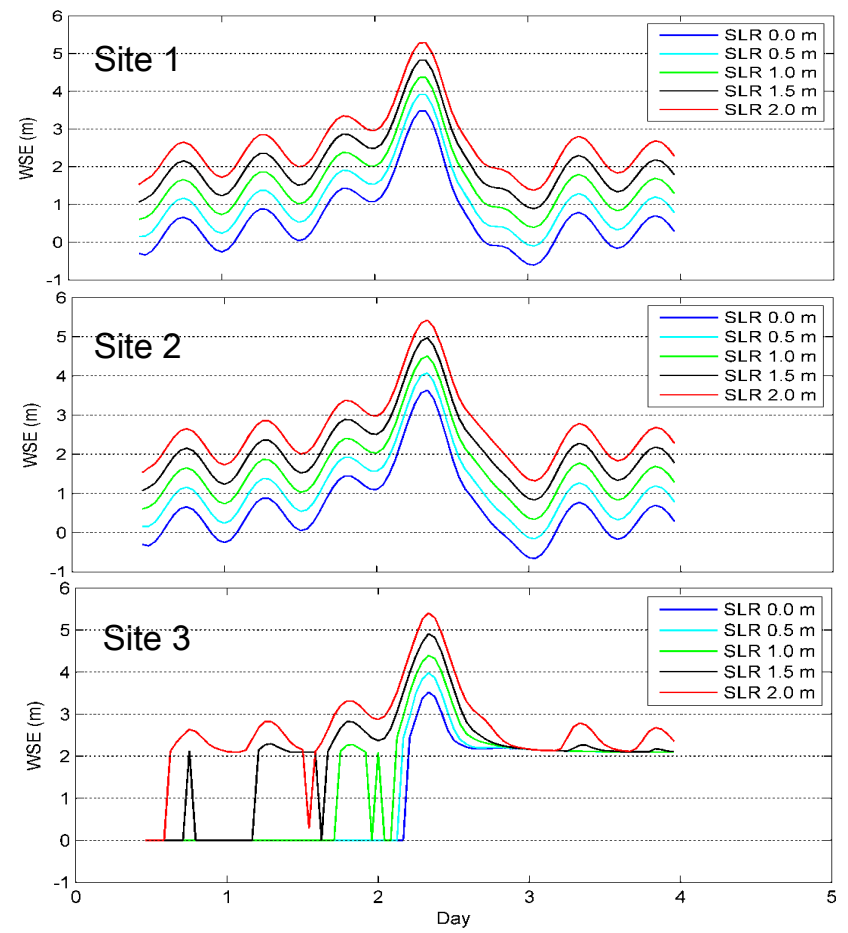

Figure 11. Water surface elevation of 100 -year return tropical storm under the existing condition $(0 \mathrm{~m})$ and the four sea level rise scenarios at Sites 1, 2, and 3. 
Table 2 lists the areas inundated due to the 50-year, 100-year, and the winter storms with different sea level rise scenarios for the Naval Station Norfolk. The results show that the flooded area expands as the sea level rise increases from 0.5 to $2.0 \mathrm{~m}$. Comparing the results among the three storms, it can be seen that the 50-year storm causes the least flooding and the 100-year storm inundates most of the area for different sea level rise scenarios. Surge generated by all three storms will inundate approximately $70-80 \%$ of the Naval Station Norfolk under the 2-m sea level rise scenario.

\begin{tabular}{|c|c|c|c|c|c|c|}
\hline \multirow{2}{*}{$\operatorname{SLR}(m)$} & \multicolumn{2}{|c|}{ 50-Year Return Storm } & \multicolumn{2}{|c|}{ 100-Year Return Storm } & \multicolumn{2}{|c|}{ Northeaster } \\
\hline & Area & $\%$ & Area & $\%$ & Area & $\%$ \\
\hline 0.0 & 1.176 & 8.11 & 9.076 & 62.57 & 1.662 & 11.46 \\
\hline 0.5 & 2.720 & 18.75 & 10.219 & 70.45 & 3.839 & 26.47 \\
\hline 1.0 & 4.948 & 34.11 & 10.762 & 74.20 & 7.326 & 50.51 \\
\hline 1.5 & 8.198 & 56.52 & 11.078 & 76.37 & 9.811 & 67.64 \\
\hline 2.0 & 10.014 & 69.04 & 11.317 & 78.02 & 10.626 & 73.26 \\
\hline
\end{tabular}

\section{WAVES}

The maximum significant wave heights through the 100 -year storm simulations corresponding to 0 and 2-m sea level rise are shown in Figure 12. Specified in the CMS, large significant wave heights near the open boundaries propagate into the model domain, decrease, and break as waves approach nearshore and harbor areas or overtop low land areas. Wave activities over the Naval Station Norfolk have a consistent coverage pattern with that due to storm surge. Wave heights on the military base generally have the amplitude of a few centimeters. Relative larger waves of more than $1 \mathrm{~m}$ can be identified from the figure, which are situated close to the oceanfront of the Naval Base under different sea level rise scenarios. North of the CMS domain extreme wave heights can go as high as $6 \mathrm{~m}$ under the $1.5-\mathrm{m}$ and $2.0-\mathrm{m}$ sea level rise scenarios. The time series of forcing conditions and model output reveal that waves propagating from the Chesapeake Bay side encounter strong opposite wind- and tideinduced currents along the navigation channels as the storm passes over the area. The energy received from the currents results in significant increase of wave heights.
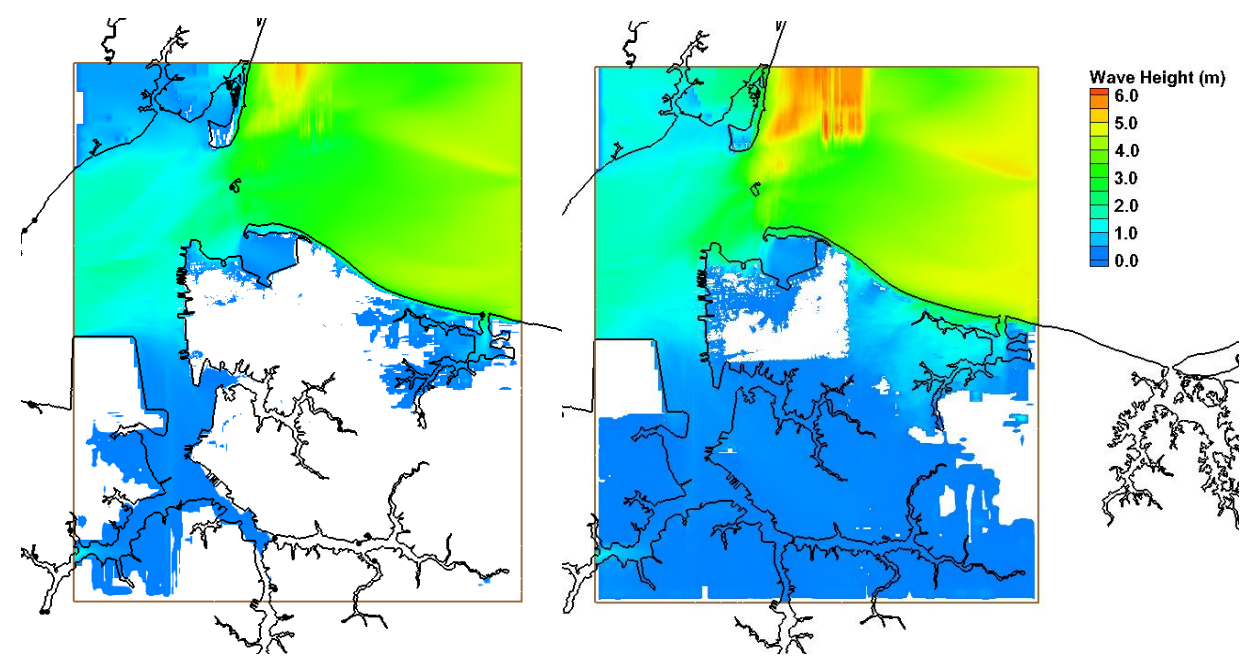

Figure 12. The maximum wave height due to 100 -year return tropical storm under the existing condition and the $2.0-\mathrm{m}$ sea level rise scenario.

Figures 13, 14, and 15 show the time series of significant wave height, wave period, and wave direction at Sites S1, S2, and S3, respectively. The wave direction follows meteorological convention where a wave direction of $0^{\circ}$ indicates the wave propagation from north. Wave parameters displayed at 
S1 are similar to waves specified at the open boundary (Figure 7). Waves evidently dissipate and diffract as entering the Hampton Roads area and travel near coast.

Site 1
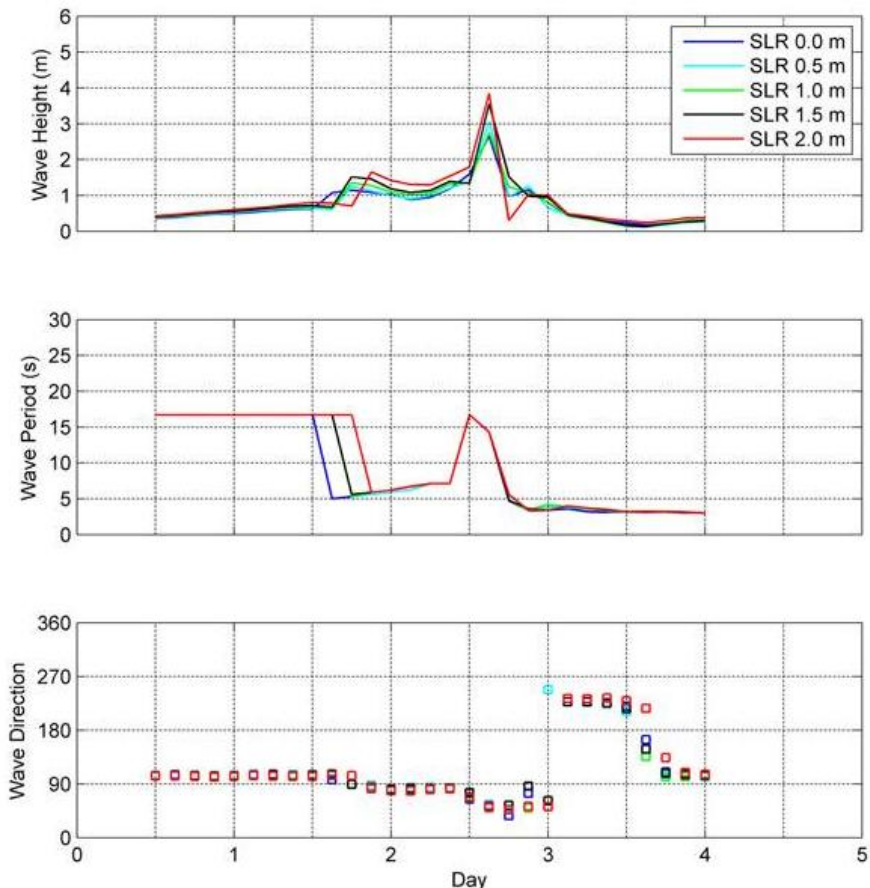

Figure 13. Wave parameters of 100 -year return tropical storm under the existing condition $(0 \mathrm{~m})$ and the four sea level rise scenarios at Site 1.

Site 2
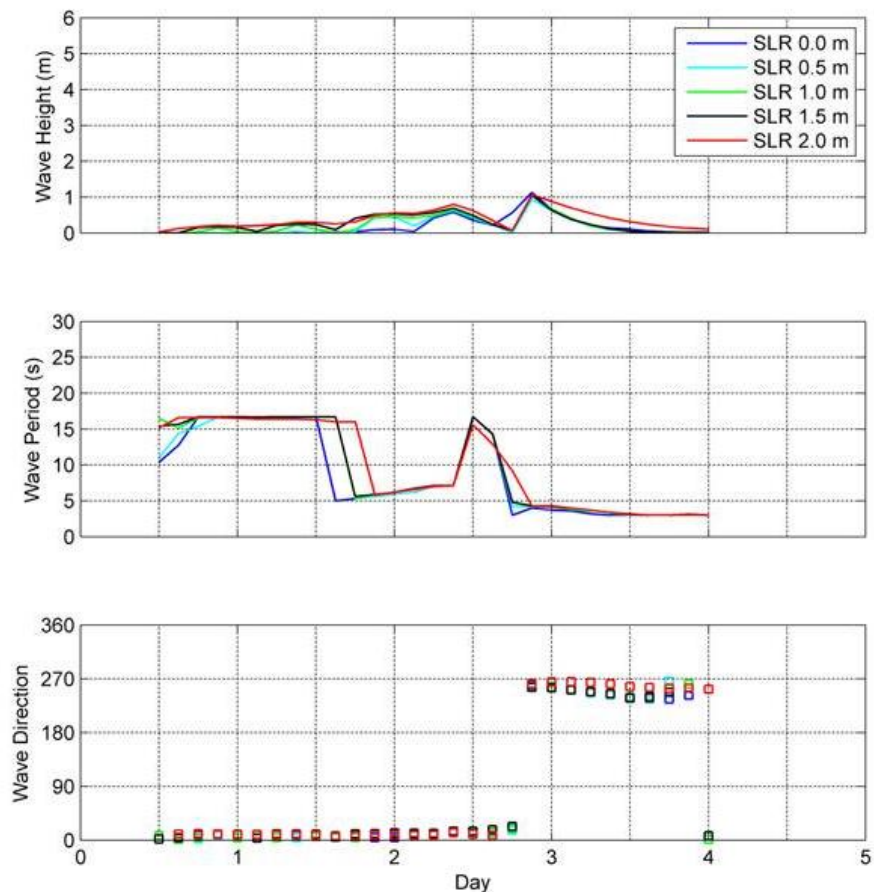

Figure 14. Wave parameters of 100 -year return tropical storm under the existing condition $(0 \mathrm{~m})$ and the four sea level rise scenarios at Site 2. 
Site 3
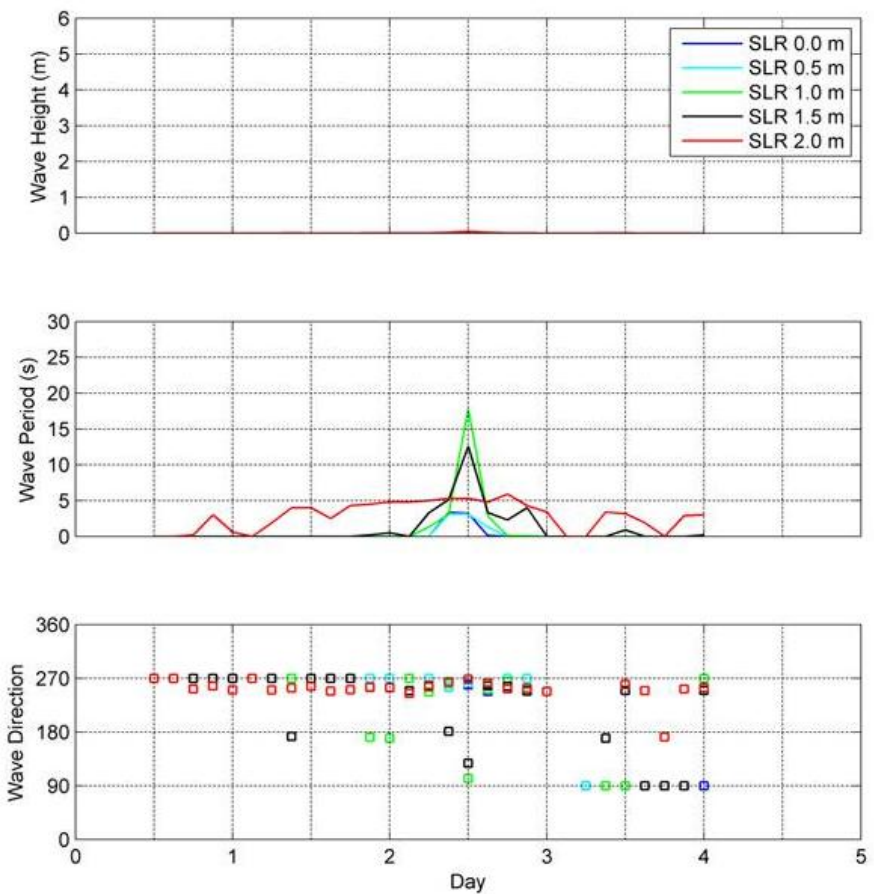

Figure 15. Wave parameters of 100-year return tropical storm under the existing condition $(0 \mathrm{~m})$ and the four sea level rise scenarios at Site 3.

The coastal effects on wave propagation are further demonstrated by wave parameters at Site 2 (Figure 14). Small short-period wind waves are mostly propagating from west and long-period swells are reaching Site 2 from north under the existing condition and different sea level rise scenarios. Wave activities on the flooded original land areas are insignificant as shown at Site 3.

\section{Sediment Transport}

The areas of interest include the Naval Station Norfolk and the navigation channels. Because a large area of the military installation is covered by concrete and buildings, for sediment transport calculations, most of the Naval Station is represented as "hard bottom" (non-erodible) and only small part of the Station as erodible depending on the land coverage properties (Figure 4). The sandy bottoms are represented in the estuarine system and a median grain size of $0.2 \mathrm{~mm}$ is specified in the CMS.

Figure 16 shows the calculated morphology changes corresponding to the 100 -year return storm for 0.0 and 2-m sea rise scenarios, respectively. Most of the sediment activities occur along the navigation channels, and the erosion and accretion pattern looks very similar for different sea level rise scenarios. The maximum erosion and accretion values are between 3.0 to $3.5 \mathrm{~m}$ with the average morphology changes less than $1.0 \mathrm{~m}$ along the channels.

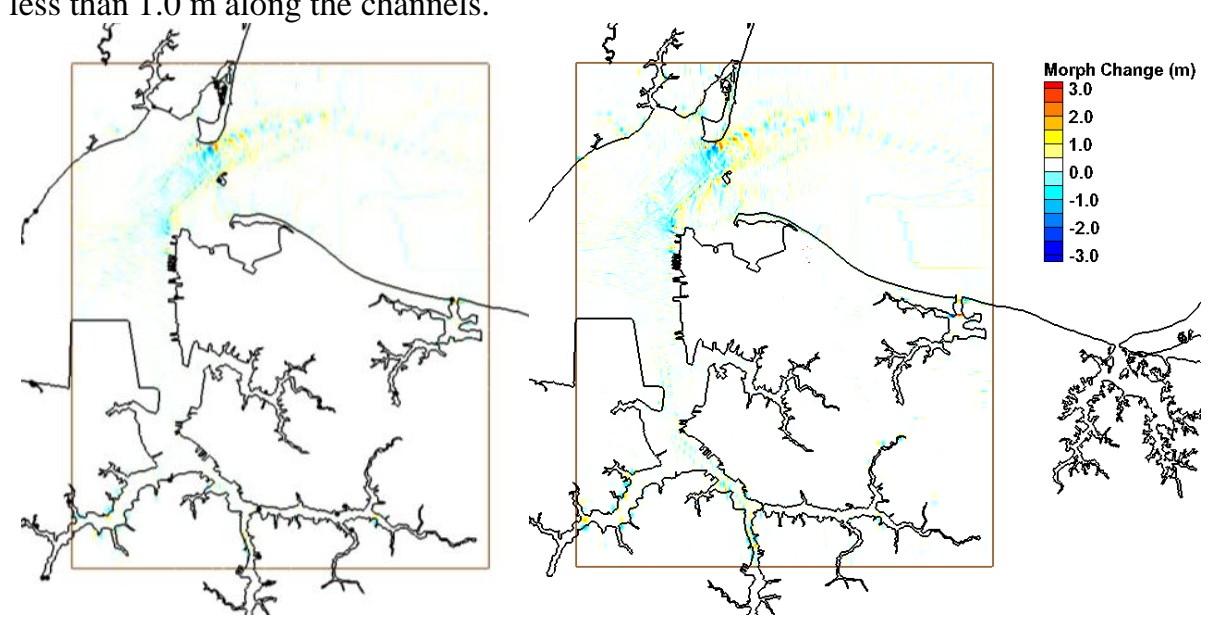

Figure 16. Morphology change due to 100 -year return tropical storm under the existing condition $(0 \mathrm{~m})$ and the $2.0-\mathrm{m}$ sea level rise scenario. 
Figure 17 shows the time series of depth changes at Sites 1, 2, and 3. More sediment movement occurs in the main navigation channel due to the passage of the storm. Site 1 appears to be a net accretion site. In response to the increase of sea level rises, an increase of accretion occurs at this site with higher deposition rates. The maximum accretion at Site 1 is approximately $2.3 \mathrm{~m}$ under the $2.0-\mathrm{m}$ sea level rise scenario. Unlike the deposition pattern displayed at Site 1, the storm condition results in a net volume loss at Site 2. A higher sea level rise corresponds to greater erosion rates (Figure 17). The maximum erosion at Site 2 is about $1.7 \mathrm{~m}$ under the $2.0-\mathrm{m}$ sea level rise scenario. Figure 17 shows no significant sediment activities at the land location, Site 3 .

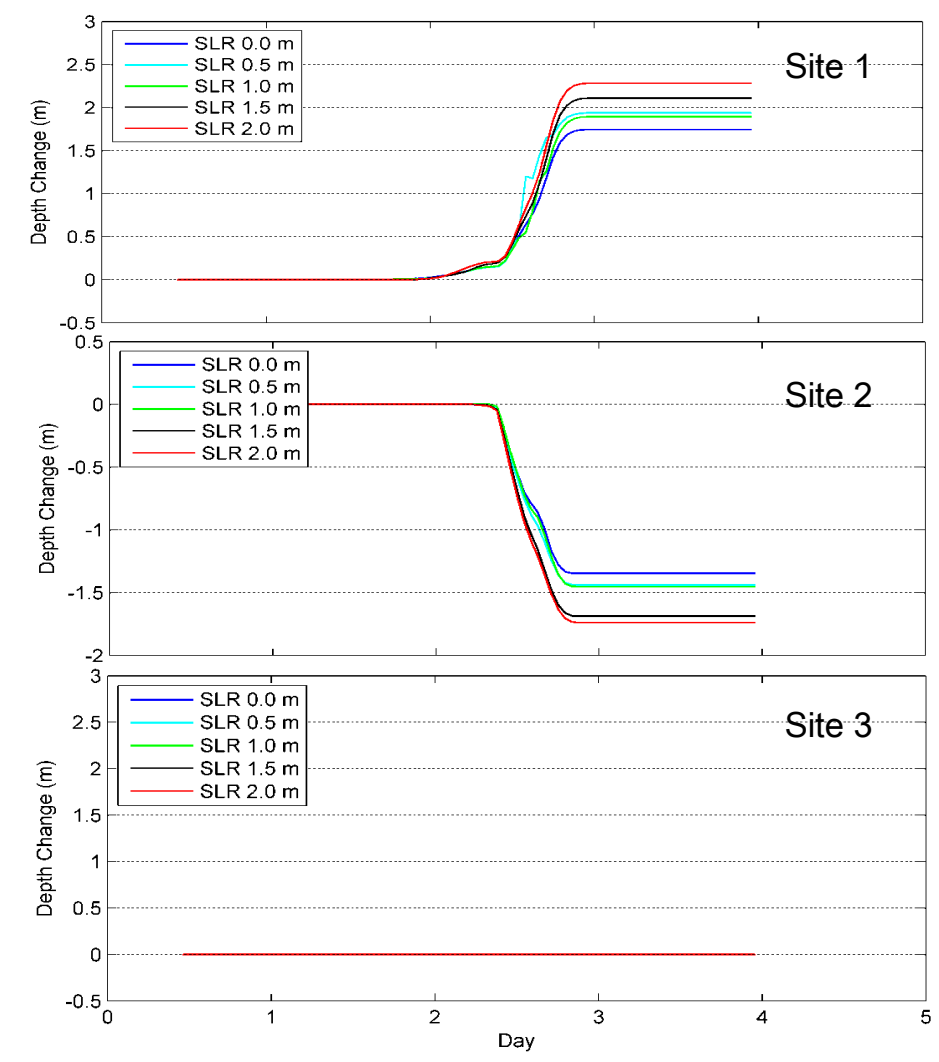

Figure 17. Depth change due to 100 -year return tropical storm under the existing condition $(0 \mathrm{~m})$ and the four sea level rise scenarios at Sites 1, 2, and 3.

To estimate total sediment volume changes in the main navigation channel, a polygon area is predelineated and shown in Figure 9. The morphology and bed volume changes within the channel are estimated at the end of the 4-day simulation. Table 3 shows the total sediment volume changes for three storms under the existing condition and four sea level rise scenarios.

\begin{tabular}{|c|c|c|c|}
\hline \multicolumn{4}{|c|}{$\begin{array}{l}\text { Table 3. Channel volume changes in Hampton Roads }\left(10^{5} \mathrm{~m}^{3}\right) \text { for } \\
\text { three storms under different sea level rise scenarios. Positive } \\
\text { indicates accretion and negative erosion. }\end{array}$} \\
\hline $\operatorname{SLR}(\mathrm{m})$ & $\begin{array}{c}50-\text { Year Return } \\
\text { Storm }\end{array}$ & $\begin{array}{c}100-\text { Year } \\
\text { Return Storm }\end{array}$ & Northeaster \\
\hline 0.0 & -1.195 & -2.616 & -1.362 \\
\hline 0.5 & -1.354 & -2.495 & -1.467 \\
\hline 1.0 & -1.346 & -3.364 & -1.986 \\
\hline 1.5 & -1.686 & -3.906 & -2.238 \\
\hline 2.0 & -1.664 & -4.745 & -1.727 \\
\hline
\end{tabular}


The negative values in Table 3 indicate that the storms induce net volume loss for different sea level rise scenarios within the area selected in the channel, which corresponds to the 50-year, the 100year return storms and the Northeaster. More erosion occurs with the sea level rise from 0.5 to $2.0 \mathrm{~m}$ and the general trend of variation of volume changes is similar to the areas inundated for the three storms (Table 2). Among the three storms, the 50-year return storm produces the least erosion rates and the 100-year return storm the most erosion rates. The volume loss for the 100 -year storm almost triples that for the 50-year storm. The results in Table 3 simply imply possible channel cleanup due to strong storms.

\section{SUMMARY}

A coupled wave, circulation and sediment transport numerical modeling system, the CMS, was applied to simulate nearshore surge, waves, and sediment transport, and to examine potential effects of sea-level rise triggered by climate change and storm surge surrounding the Naval Station Norfolk. The existing condition and four sea level rise scenarios, $0.5,1.0,1.5$, and $2.0 \mathrm{~m}$, were selected for the study. Corresponding to those scenarios the simulations include two synthetic storms (50-year return and 100year return), and one winter storm (northeaster).

The model results show that the maximum surge level induced by the 100 -year storm would reach to $3.6 \mathrm{~m}$ under the existing condition and to $5.4 \mathrm{~m}$ under the $2.0-\mathrm{m}$ sea level rise scenario. Associated with the storm surge and sea level rises, extensive inundation occurs at the Naval Station Norfolk. For the three storms simulated the surge levels are high enough to inundate approximately $70-80 \%$ of the Naval Station Norfolk under the 2-m sea level rise scenario.

Incident waves are provided along the CMS model's open boundaries where significant wave heights are correlated with different sea level rises. Both long-period swells and short-period wind waves are identified within the CMS domain. For the 100-year return storm, the peak wave heights range from 2.5 to $3.8 \mathrm{~m}$ corresponding to the existing condition and four sea level rise scenarios. Significant wave heights on the Naval Station Norfolk have the amplitude of a few centimeters and relative larger waves are only found at the seaward limit of the Naval Base.

Calculated morphology changes show that the sediment movement mostly occurs in the navigation channels and the maximum depth changes are more than $3.0 \mathrm{~m}$ along the channels. In general, the amount of erosion and deposition increases as the value of sea level rise goes up. The morphology and bed volume changes indicate that the 50-year, 100-year return storms, and the Northeaster induce a net volume loss for different sea level rise scenarios within the channel area. The results indicate that stronger storms may act to flush the channels in the Hampton Roads area.

Comparing among three simulated storms, the 50-year return storm generates the lowest surge level to inundate the smallest land area at the Naval Station Norfolk, and produces the least volume change in the main navigation channel under the same sea level rise condition. On the other hand, the 100-year return storm with the highest surge level inundates the largest land area and causes the most erosion under the same sea level rise condition.

\section{ACKNOWLEDGMENTS}

The authors are grateful for the financial support by the Resource Conservation and Climate Change Program Area of the Strategic Environmental Research and Development Program (SERDP) and by the Coastal Inlets Research Program (CIRP) administered at Coastal and Hydraulics Laboratory under the Navigation Program for Headquarters, U.S. Army Corps of Engineers (HQUSACE). We would also like to thank the late Dr. Nicholas C. Kraus for his inspiration and encouragement towards the CMS application to and Dr. Julie D. Rosati and Dr. Zeki Demirbilek for their review and advice on this study. Permission was granted by the Chief, U. S. Army Corps of Engineers to publish this information.

\section{REFERENCES}

Burks-Copes, K. A., and E. J. Russo. 2011. Risk Quantification for Sustaining Coastal Military Installation Assets and Mission Capabilities. Interim Technical Report. U.S. Army Engineer Research and Development Center, Environmental Laboratory, Vicksburg, MS. 
Buttolph, A. M., C. W. Reed, N. C. Kraus, N. Ono, M. Larson, B. Camenen, H. Hanson, T. Wamsley, and A. K. Zundel. 2006. Two-dimensional depth-averaged circulation model CMS-M2D: Version 3.0, Report 2, sediment transport and morphology change. Coastal and Hydraulics Laboratory Technical Report ERDC/CHL-TR-06-7. Vicksburg, MS: U.S. Army Engineer Research and Development Center.

Downer, C. W. and F. L. Ogden, 2004. GSSHA: A model for simulating diverse streamflow generating processes. Journal of Hydrologic Engineering 9(3):161-174.

Intergovernmental Panel on Climate Change (IPCC). 2007. Fourth assessment report. Available online at: http://www.ipcc.ch/.

Hirsch, M. E., A. T. DeGaetano, and S. J. Colucci. 2001. An east coast winter storm climatology. J. Climate 14: 882-899.

Lin, L., Z. Demirbilek, H. Mase, J. Zheng, and F. Yamada. 2008. CMS-Wave: A nearshore spectral wave processes model for coastal inlets and navigation projects. ERDC CHL. Vicksburg, MS.

Mase, H. 2001. Multidirectional random wave transformation model based on energy balance equation. Coastal Engineering Journal 43(4):317-337.

McAlpin, T., T. Wamsley, and M. Cialone. 2011 (In Press). Methodology for modeling the effects of sea level rise with the ADCIRC numerical model. ERDC/CHL TN-CHETN-IV-x. Vicksburg, MS: U. S. Army Engineer Research and Development Center.

Mclean, R. F., A. Tsyban, A. Burkett, J. O. Codignotto, D. L. Forbes, N. Mimura, R. J. Beamish, and V. Ittekkot. 2001. Coastal zones and marine ecosystems. In: Mccarthy, J. J., O. F. Canziani, N. A. Leary, D. J. Dokken, and K. S. White, (eds.), Climate Change 2001: Impacts, Adaptation and Vulnerability. Cambridge: Cambridge University Press: 343-380.

Melby, J. A., E. F. Thompson, M. A. Cialone, J. M. Smith, L. E. Borgman, Z. Demirbilek, J. L. Hanson, and L. Lin. 2005. Life-cycle analysis of mid-bay and Poplar Island projects, Chesapeake Bay, Maryland. Coastal and Hydraulics Laboratory Technical Report ERDC/CHL-TR-05-12. Vicksburg, Mississippi: U.S. Army Engineer Research and Development Center.

Pfeffer, W. T., J. T. Harper, and S. O'Neel. 2008. Kinematic constraints on glacier contributions to $21^{\text {st }}$-century sea-level rise. Science 321:1340-1343.

Slawson, T. R, and J. T. Brokaw. 1995. Development of a three dimensional in-structure shock model (ISS3D). ARA Technical Report. Vicksburg, MS: Applied Research Associates.

Smith, E.. 1999. Atlantic and east coast hurricanes 1900-98: a frequency and intensity study for the twenty-first century. Bulletin of the American Meteorological Society 80(12):2717-2720.

Taylor, L. A., B. W. Eakins, K. S. Carignan, R. R. Warnken, T. Sazonova, D. C. Schoolcraft, and G. F. Sharman. 2008. Digital Elevation Model of Virginia Beach, Virginia: procedures, data sources and analysis. NOAA Technical Memorandum NESDIS NGDC-7. National Geophysical Data Geophysics Division, Boulder, Colorado.

Zundel, A. K., 2006. Surface-water modeling system reference manual - Version 9. 2. Provo, UT: Brigham Young University Environmental Modeling Research Laboratory. 